Forest Ecology and Management 260 (2010) 787-794.

doi:10.1016/j.foreco.2010.05.037

\title{
Impact of wildfire intensity and logging on fungal and nitrogen-cycling bacterial communities in British Columbia forest soils
}

Nabla Kennedy ${ }^{1}$ and Keith N. Egger ${ }^{1 *}$

${ }^{1}$ Ecosystem Science and Management Program, University of Northern British Columbia, 3333 University Way, Prince George, BC, V2N 4Z9, Canada.

Nabla Kennedy: nabla.kennedy@gmail.com

Keith N. Egger: egger@unbc.ca

*Corresponding author: Mailing address: Ecosystem Science and Management Program, University of Northern British Columbia, 3333 University Way, Prince George, BC, V2N 4Z9, Canada. Phone: +1-250-960-5860. Fax: +1-250-960-5539. E-mail: egger@unbc.ca 


\begin{abstract}
Wildfire and logging are common disturbances in the forests of northwestern North America, causing changes in soil chemistry and microbiology, including fungal and nitrogen-cycling bacterial communities. These organisms play key roles in nutrient cycling, and affect the regeneration of tree seedlings after disturbance. We studied the effects of wildfire and logging on fungal and nitrogen-cycling communities in the rhizosphere of 16 month-old Douglas-fir seedlings as they regenerated in burned and logged soils. Seeds were planted against root windows that were set up vertically in the soil, with a removable front panel used to access the seedling rhizosphere soil surface. Windows were established in control, lightly burned, and severely burned plots, as well as two types of logged plots (clearcut and screefed clearcut). Soil scrapings from the root window-soil interface were taken and the structure of fungal and nitrogen-cycling communities was resolved using length-heterogeneity PCR (LH-PCR) of fungal nuclear ribosomal RNA, and terminal restriction fragment length polymorphism (T-RFLP) analysis of nifH and nos $Z$ genes. We found striking differences in the community structure of fungal, denitrifying, and $\mathrm{N}$-fixing communities in response to burning and logging. With the exception of clearcut and screefed clearcut, which were generally similar, each treatment had a unique impact on community structure for these genes. Burning and logging also impacted the relative richness and evenness of these communities. Fungal relative richness and evenness increased in response to logging and severe burning, while denitrifier relative richness and evenness increased in all disturbance treatments, and $\mathrm{N}$-fixing bacterial relative richness and evenness decreased in response to burning. The greatest differences in microbial community structure, relative
\end{abstract}


richness, and evenness were found in the comparisons of lightly burned and logged treatments. The results suggest that the presence of an intact forest floor influences soil microbial communities less than the presence of living trees.

Keywords: fire; logging; T-RFLP; nifH; nosZ; fungi

\section{Introduction}

Temperate and sub-boreal forests are subject to natural and man-made disturbances such as wildfire, insect infestations, and clearcutting. The extent and severity of these disturbances are likely to increase as climate change causes higher temperatures and increased drought (Hamann and Wang, 2006). Undisturbed forest communities tend to be biologically stable, with indigenous microbial populations maintaining balanced nutrient cycles (Paul and Clark, 1989). Disturbances such as fire and clearcutting alter both aboveground forest properties (removal of trees and soil) and belowground soil chemistry, microbial communities, and nutrient cycling (Ballard, 2000; Bárcenas-Moreno and Bååth, 2009; Goodale and Aber, 2001; Jiménez Esquilin et al., 2008; Yeager et al., 2005). These changes can affect the regeneration of ecologically and commercially valuable tree species such as Douglas-fir (Pseudotsuga menziesii). In disturbed areas, interactions between seedling roots and soil microbes may be crucial to seedling survival. Colonization of seedling roots by ectomycorrhizal $(\mathrm{EcM})$ fungi can provide greater access to nutrients and water (Schoonmaker et al., 2007) and promote carbon cycling (Talbot et al., 2008). Bacteria associated with EcM are known to mobilize key nutrients from minerals and organic substrates (Burke et al., 2008; Frey-Klett et al., 2007), while 
many key processes, such as nitrogen fixation, can be carried out by bacteria living freely in the soil (Izquierdo and Nüsslein, 2006).

Fungi account for the bulk of microbial biomass in forest soils, and play major roles in nutrient-cycling processes either as free-living saprotrophs or as mycorrhizae (Dighton, 2003). EcM fungi, in particular, play a pivotal role in Douglas-fir seedling establishment (Simard, 2009; Twieg et al., 2007). Fire has been demonstrated to alter the community structure of both soil fungi (Bárcenas-Moreno and Bååth, 2009; Cairney and Bastias, 2007) and EcM fungi (Dahlberg et al., 2001; Smith et al., 2004). Similarly, clearcut logging can alter forest fungal composition, with different EcM fungi found in clearcuts compared to undisturbed forests (Jones et al., 2003).

Nitrogen is typically the limiting nutrient in northern forest soils (Widmer et al., 1999). Burning and logging cause long-term changes in N-cycling (Goodale and Aber, 2001), affecting the size of $\mathrm{N}$ pools in soils (Grogan et al., 2000; Neary et al., 1999; Wan et al., 2001) and the composition of N-cycling microbial communities (Reich et al., 2001; Shaffer et al., 2000; Walley et al., 1996). Nitrogen fixation is carried out by a wide range of heterotrophic bacteria, but all have in common the gene for nitrogenase reductase (nifH), making it an ideal molecular marker (Zehr et al., 2003). Denitrifying bacteria are a similarly heterogeneous group, but focusing on the gene encoding dinitrogenase reductase (nosZ) allows detection of organisms that are capable of completing the denitrification cycle (Throbäck et al., 2004). 
In recent years, molecular advances have allowed ecologists using techniques such as length-heterogeneity polymerase chain reaction (LH-PCR) and terminal restriction fragment length polymorphism (T-RFLP) to quickly profile microbial populations in the environment (Thies, 2007). These "fingerprinting" techniques provide a powerful way to gain information about the relative richness of the targeted gene (number of genotypes), while the fragment peak height gives some indication of the relative abundance of each genotype within a soil sample. By targeting functional genes, DNA-based community structure can be linked to potential ecosystem function. Although the extent of the relationship between genetic community structure and physiological function has not yet been proven (Wallenstein et al., 2006), there is evidence of coupling between the two (Kandeler et al., 2006; Rich et al., 2003), and analysis of functional genes remains a useful method for investigating changes in specific functional communities.

In the summer of 2003, large portions of the southern BC interior were burned by forest fire. This provided a unique opportunity to study the effect of wildfire on microbial communities. In order to separate the effects of burning from those of manual tree removal and forest floor reduction, we planted interior Douglas fir (Pseudotsuga menziesii var. glauca (Beissn.) Franco) seeds in areas burned to different severities, established forests, clearcuts, and screefed clearcuts. We examined shifts in the community structure of soil fungi using LH-PCR, and of nitrogen-fixing and denitrifying microbes using T-RFLP analysis of nifH and nosZ genes, respectively.

\section{Materials and methods}




\subsection{Site descriptions}

The study was established over an $850 \mathrm{~km}^{2}$ area in the Cascade Dry, Cool variant of the Interior Douglas-fir biogeoclimatic zone, near the town of Barriere, British Columbia $(51.12 \mathrm{~N}, 120.07 \mathrm{~W})$. This was where the McLure fire burned 26,000 ha of forest in the summer of 2003. The 12 sites were circum-mesic in soil moisture regime and ranged in elevation from 806 to 1268 masl. The original canopy at all sites was dominated by interior Douglas-fir, with minor components of lodgepole pine (Pinus contorta var. latifolia) (Stark et al., 2006). Sites classified as 'high severity burns' had been exposed to a stand-destroying wildfire, with all needles on the trees consumed during the fire. At these sites, it was apparent from the exposed mineral soil that most of the forest floor had been consumed $(0.7 \pm 0.2 \mathrm{~cm}$ depth compared to $4.9 \pm 0.6 \mathrm{~cm}$ in control mature forests). The remaining burned trees on these sites were salvage logged over the winter and early spring of 2004, before the initiation of our study. Sites classified as 'low severity burns' were exposed to surface-level fire. At these sites, at least $80 \%$ of the trees survived immediately after the fire. The understory vegetation was consumed and there was evidence that a good portion of the forest floor was lost during the fire $(1.8 \pm 0.5 \mathrm{~cm})$. The clearcut sites, which had been logged in the summer of 2003, contained two types of forest floor disturbance: none $(3.8 \pm 0.4 \mathrm{~cm}$ depth) or with the forest floor removed to expose mineral soil ( $0 \mathrm{~cm}$ of forest floor). The clearcuts and control mature forests were located either within the overall perimeter or at the immediate periphery (within $4 \mathrm{~km}$ ) of the McLure fire.

\subsection{Experimental design}


The study was established as a completely randomized design with three replicate sites of each of four disturbance treatments: control forests, clearcuts, forests disturbed by low severity burns, and forests disturbed by high severity burns. Clearcut sites had two types of plots: those with the forest floor left undisturbed and those with the organic horizons removed (referred to as 'screefed clearcut'). In order to access the root/soil interface, three root windows (transparent acrylic panel $(77 \mathrm{~cm} \times 52 \mathrm{~cm} \times 0.6 \mathrm{~cm}$ ) with a $30 \mathrm{~cm} \times$ $30 \mathrm{~cm}$ trap door (Dong et al., 2007) were installed at each plot. Douglas-fir seed (Seedlot 48523 from the British Columbia Ministry of Forests Tree Seed Centre, Surrey, B.C.) was moist-stratified at $4{ }^{\circ} \mathrm{C}$ for 3-6 weeks. From late May to mid June 2004, seeds were planted $1 \mathrm{~cm}$ apart in 5-mm deep depressions, as close to the window as possible (Jones et al, in press). Pits used to access the root windows were covered throughout the experiment to maintain light levels and temperature comparable to soil conditions.

\subsection{Sampling}

Soil samples were collected from the root window interface in October 2005 using a metal grid. The $20 \times 20 \mathrm{~cm}$ square grid was composed of sixteen $5 \times 5 \mathrm{~cm}$ squares. The top of the grid was matched to the top of the forest floor at each window, and light scrapings of soil (approx. $5 \mathrm{~g}$ ) from each square were taken using wooden sticks. As the upper $5 \mathrm{~cm}$ of forest floor was often composed of litter, or eroded, only the scrapings from the 8 squares in the middle $5-15 \mathrm{~cm}$ of the grid were used, for a total of 72 soil samples for each treatment. The grid was placed on the vertical surface of the root window. The soil was collected into plastic bags and kept at $4^{\circ} \mathrm{C}$ while transported back to the laboratory, where it was frozen at $-20^{\circ} \mathrm{C}$ until DNA extraction. 


\subsection{Soil chemical analysis}

The soil mineral layer was sampled in September 2004 (Jason Barker, University of British Columbia, personal communication). The top horizons of forest floor were removed to expose mineral soil. Using a hand held soil corer, five subsamples per site were taken, combined, and sent to the British Columbia Ministry of Forests, Research Branch Analytical Laboratory in Victoria, British Columbia. Soils were analyzed for total C, available P (Bray) and pH (water) according to Kalra and Maynard (1991). Mineralizable $\mathrm{N}$ (as $\mathrm{NH}_{4} \mathrm{~N}$ ) was determined using a two week anaerobic incubation (Bremner, 1996).

\subsection{DNA preparation}

DNA from all soil samples was extracted using Ultraclean Soil DNA kits (MoBio, Carlsbad, CA, USA), following the manufacturer's recommended alternative protocol for increased yield.

\subsection{PCR amplification of the fungal community ( $L H-P C R)$}

A segment of the fungal rDNA intergenic spacer region containing part of the 5.8S rRNA gene, the second internal transcribed spacer (ITS2), and a portion of the 18S rRNA gene was amplified using primer set ITS3 (GCATCGATGAAGAACGCAGC) (White et. al., 1990) and NLB4 (GGATTCTCACCCTCTATGAC) (Martin and Rygiewicz, 2005). The reverse primer NLB4 was labeled with WellRed fluorescent dye D3 (Integrated DNA Technologies). Each $30 \mu \mathrm{L}$ PCR reaction contained $0.6 \mu \mathrm{L}$ undiluted genomic DNA, $1 \mathrm{X}$ 
PCR Buffer, $0.2 \mathrm{mM}$ dNTPs, $2.0 \mathrm{mM} \mathrm{MgCl} 2,0.04 \mu \mathrm{M}$ of each primer, and $0.7 \mathrm{U}$ Platinum Taq DNA Polymerase (Invitrogen). Thermocycler conditions were: an initial denaturing, annealing and extension cycle of $94^{\circ} \mathrm{C}$ for 4 minutes, $48^{\circ} \mathrm{C}$ for 1 minute, and $72^{\circ} \mathrm{C}$ for 2 minutes, followed by 35 cycles of $94^{\circ} \mathrm{C}$ for 30 seconds, $48^{\circ} \mathrm{C}$ for 30 seconds, and $72^{\circ} \mathrm{C}$ for 1 minute 30 seconds. The final extension required 6 minutes 30 seconds at $72^{\circ} \mathrm{C}$.

\subsection{PCR amplification of the nitrogen-fixing community (nifH gene)}

The half-nested nifH protocol used Nh21F (5'-GCIWTITAYGGNAARGGNGG-3') and WidNhR (5'-GCRTAIABNGCCATCATYTC-3') for the primary PCR reaction (Widmer et al., 1999), and Nh21F and Nh428R (5'-CCRCCRCANACMACGTC-3') for the second amplification (Deslippe et al., 2004). The reverse primer Nh428R was labeled with WellRed fluorescent dye D4 (Integrated DNA Technologies). Each 31.2 $\mu \mathrm{L}$ PCR reaction contained $4.5 \mu \mathrm{L}$ 1:10 dilutions of genomic DNA, 1X PCR Buffer, $0.2 \mathrm{mM}$ dNTPs, $2.0 \mathrm{mM} \mathrm{MgCl} 2,0.04 \mu \mathrm{M}$ of each primer, and $0.75 \mathrm{U}$ Platinum Taq DNA Polymerase (Invitrogen). Thermocycler conditions were the same for both reactions: a 1 minute denaturation step at $94^{\circ} \mathrm{C}$ was followed by 35 cycles of denaturing, annealing and extension at $94^{\circ} \mathrm{C}$ for 45 seconds, $53^{\circ} \mathrm{C}$ for 45 seconds, and $72^{\circ} \mathrm{C}$ for 1 minute 30 seconds respectively. The final extension required 10 minutes at $72^{\circ} \mathrm{C}$.

\subsection{PCR amplification of the denitrifying community (nosZ gene)}

The nos Z gene was amplified using the primers nosZ-F (5'CGYTGTTCMTCGACAGCCAG-3') and nos1773R (5'- 
AACGAVCAGYTGATCGAYAT-3') (Throbäck et al., 2004). The reverse primer was labeled with WellRed fluorescent dye D4 (Integrated DNA Technologies). Each $30 \mu \mathrm{L}$ PCR reaction contained $3 \mu \mathrm{L} \mathrm{1:10}$ dilutions of genomic DNA, 1X PCR Buffer, $0.2 \mathrm{mM}$ dNTPs, $2.125 \mathrm{mM} \mathrm{MgCl}_{2}, 0.04 \mu \mathrm{M}$ of each primer, and $0.75 \mathrm{U}$ Platinum Taq DNA Polymerase (Invitrogen). A touchdown thermocycling program was employed: a 2 minute denaturation step at $94^{\circ} \mathrm{C}$ was followed by 5 cycles of denaturing, annealing and extension respectively at $94^{\circ} \mathrm{C}$ for 30 seconds, $60^{\circ} \mathrm{C}$ for 1 minute, and $72^{\circ} \mathrm{C}$ for 1 minute, with the annealing temperature decreasing by $0.5^{\circ} \mathrm{C}$ each time. This was followed by 29 cycles of denaturing, annealing and extension respectively at $94^{\circ} \mathrm{C}$ for 30 seconds, $58^{\circ} \mathrm{C}$ for 1 minute, and $72^{\circ} \mathrm{C}$ for 1 minute. The final extension required 10 minutes at $72^{\circ} \mathrm{C}$.

\subsection{Assessment and digestion of PCR products}

PCR product success and quality was assessed by $1 \%$ agarose gel electrophoresis and visualized by staining with ethidium bromide. Amplicons of expected size were cleaned via ethanol precipitation and then resuspended in ultrapure water (Integrated DNA Technologies). A restriction digest was performed on nifH and nos $Z$ amplicons to prepare them for T-RFLP analysis. For each reaction, $6 \mu \mathrm{L}$ of PCR product was digested with 2.5 $\mathrm{U}$ MboI (for nifH), or HhaI (for nosZ) enzyme and $1 \mathrm{X}$ of the corresponding REACT buffer (Invitrogen). This enzyme was selected based upon number of restriction sites targeted (and therefore fragments generated); a series of endonucleases were tested on replicate samples and the one that identified the greatest amount of variation was chosen. Digests were incubated at $37^{\circ} \mathrm{C}$ for at least 5 hours and the reactions were terminated at 
$65^{\circ} \mathrm{C}$ for 10 minutes. Digested fragments were desalted by ethanol precipitation and resuspended in $8 \mu \mathrm{L}$ of ultrapure water.

\subsection{LH-PCR and T-RFLP analysis}

Fragments were prepared for analysis as suggested by the manufacturer for the BeckmanCoulter CEQ8000 Fragment Analysis System. Two microliters of LH-PCR product or 2 $\mu \mathrm{L}$ of digested nifH or nos $Z$ PCR product were combined with $0.5 \mu \mathrm{L}$ of 600 size standard and brought up to $40 \mu \mathrm{L}$ with Sample Loading Solution (Beckman Coulter Inc.). Fragment lengths were determined by electrophoresis using a Beckman Coulter (CEQ8000) automated sequencer, version 6.0.2. Analysis of fragment profiles was performed using the Beckman Coulter AFLP analysis package 8000, version 8.0.52, analysis algorithm version 2.2.1. Bin width was set to $1 \mathrm{bp}$, and fragments contributing $<1 \%$ of the total peak height of a sample were removed. For LH-PCR, only fragments from the 400-700 bp range were included. The relative abundance of genotypes in each sample was calculated after relativizing the fluorescent signal strength of each fragment peak to the total peak area within each sample (Osborne et al., 2006). MRPP analysis was performed after these relativizations, and relative richness and evenness were determined using indices described by Blackwood et al. (2007): richness (S) and Smith and Wilson evenness $\left(\mathrm{E}_{\mathrm{var}}\right)$. The program RiboSort (Scallan et al., 2008) was then used to merge replicate samples from each site into one composite profile, discarding genotypes present in $<2$ replicates, for NMS analysis.

\subsection{Statistical analysis}


Soil chemistry, relative richness, and evenness results were analyzed by one-way analysis of variance using Statistica version 6.1. The significance level was set at $P<0.05$. A separate, nested ANOVA was performed on clearcut and screefed clearcut treatments to confirm one-way ANOVA results, as these treatments co-occurred on the same sites and were not independent. Post-hoc Tukey HSD tests were performed to determine significant differences between treatments. Regression analysis was performed to test for correlations between relative richness, evenness, and soil chemical variables. Multivariate statistical analysis was performed on T-RFLP and LH-PCR profiles using PC-ORD 5.12. Pairwise comparisons between treatment groups were tested with Multi-Response Permutation Procedures (MRPP) with the Sørensen distance measure. As for soil chemistry, relative richness, and evenness, a separate, nested analysis (perMANOVA) was performed on clearcut and screefed clearcut treatments to confirm results, as these treatments were not independent. Community structure was assessed graphically with Nonmetric Multidimensional Scaling (NMS) (McCune and Grace, 2002). NMS was calculated on the basis of a Sørensen (Bray-Curtis) distance measure with 100 runs with real and randomized data (compared using Monte Carlo simulations) and a maximum of 250 iterations to assess stability. Pearson and Kendall correlations with soil chemistry variables were assessed, and correlations with values higher than 0.150 were overlaid as vectors on the NMS plot.

\section{Results}

\subsection{Soil chemistry}


Soil chemistry measurements from the mineral soil layer did not exhibit significant differences according to treatment (Table 1). Both fire and logging treatments caused a decrease in $\mathrm{pH}$ relative to the control, but this was not significant. Soil carbon, nitrogen, mineral $\mathrm{N}$, and available $\mathrm{P}$ showed low variance between treatments.

\subsection{Fungi}

NMS ordination of fungal LH-PCR profiles exhibited clustering according to treatment

(Figure 1), with burned sites (light burn and severe burn) clustering on the left side of the plot, and logged sites (clearcut and screefed clearcut) to the right. Correlations were found between fungal community structure and mineral $\mathrm{N}\left(\mathrm{r}^{2}=0.310\right.$ on Axis 2$)$ and available $\mathrm{P}\left(\mathrm{r}^{2}=0.197\right.$ on Axis 1). Clustering of control samples was not evident on the NMS plot, but MRPP results indicated that all of the treatments, with the exception of clearcut and screefed clearcut, significantly $(P<0.01)$ different from each other (Table 2$)$. NMS provides a graphical 2-dimensional view of distances between samples, and thus is limited in the information it can portray, while the MRPP result reflects all the information contained in the distance matrix. Clear disturbance effects were also noted in the relative richness and evenness of fungal fingerprints (Figure 2A), with severe burn and logging treatments resulting in significant $(P<0.05)$ increases in relative richness and evenness, relative to the control. Light burn samples demonstrated increases in the relative richness and evenness of fungal fingerprints, but only the increase in evenness was significant $(\mathrm{P}<0.05)$. There were no significant correlations between the relative richness and evenness of fungal fingerprints, and soil chemical variables. 


\subsection{Denitrifiers}

NMS ordination revealed separation of nosZ T-RFLP profiles according to treatment

(Figure 3). Control sites clustered to the top left, logged sites clustered to the top middle, and burned sites clustered to the lower half of the plot. Denitrifier community structure was correlated with $\mathrm{pH}\left(\mathrm{r}^{2}=0.101\right.$ on Axis 1$)$. MRPP results confirmed the differences in community structure seen in the NMS plot, with all of the treatments significantly different from each other $(P<0.05)$ (Table 2). The number of nos $Z$ fingerprints present in each sample was used as a marker of denitrifier relative richness (Figure 2B). The relative richness of nosZ fingerprints was significantly $(P<0.05)$ increased by all disturbance treatments (light burn, severe burn, clearcutting and screefing) relative to the control. There was no significant effect of burning or logging on the evenness of nos $Z$ fingerprints, and no significant correlations between the relative richness and evenness of nosZ fingerprints, and soil chemical variables.

\subsection{N-fixing bacteria}

Similarly to fungal and nos $Z$ communities, NMS ordination of nifH T-RFLP profiles showed clustering according to treatment (Figure 4), with burned sites (light burn and severe burn) clustering on the upper right side of the plot, and logged sites (clearcut and screefed clearcut) on the bottom left. These community responses to treatment were confirmed by MRPP results, which found all of the treatments, with the exception of clearcut and screefed clearcut, significantly different from each other $(P<0.05)$ (Table 2$)$. $\mathrm{N}$-fixing bacteria community structure was correlated with Total $\mathrm{C}\left(\mathrm{r}^{2}=0.239\right), \mathrm{pH}$ $\left(\mathrm{r}^{2}=0.193\right)$, and mineral $\mathrm{N}\left(\mathrm{r}^{2}=0.161\right)$ on Axis 2 . The relative richness of $n i f H$ 
fingerprints (Figure 2C) responded more to fire than to logging treatments. Both fire treatments (light burn and severe burn) significantly decreased $(P<0.05)$ the richness of nifH fingerprints relative to the control, while both logging treatments (clearcut and screefed clearcut) increased the relative richness of $\mathrm{N}$-fixing fingerprints, but not significantly. Some significant differences in the evenness of nifH fingerprints due to treatment were noted, with light burn samples exhibiting lower evenness than logged (clearcut and screefed clearcut) samples $(P<0.05)$. There were no significant correlations between the relative richness and evenness of nifH fingerprints, and soil chemical variables.

\section{Discussion}

Our study found striking differences in the community structure of fungal, denitrifying, and $\mathrm{N}$-fixing communities in response to burning and logging. Other studies have noted similar impacts, with fire lowering soil microbial biomass in coniferous forests (Yeager et al., 2005), and both fire and screefing resulting in changes to soil bacterial and fungal composition in pine forests (Jimenez Esquilin et al., 2008). Fire has been shown to alter the community structure of mycorrhizal (Grogan et al., 2000; Smith et al., 2004) and soil fungi (Bárcenas-Moreno and Bååth, 2009; Cairney and Bastias, 2007), and clearcut logging has also been demonstrated to produce shifts in forest mycorrhizal fungal populations (Jones et al., 2003). Although fewer studies have examined the effect of fire and logging on $\mathrm{N}$-cycling bacteria in particular, long-term changes in forest $\mathrm{N}$-cycling in response to burning and logging have been demonstrated (Goodale and Aber, 2001). One study examining the impact of clearcut logging on N-fixing bacteria in Douglas-fir 
forests concluded that logging removes a unique nifH gene pool from the soil (Shaffer et al., 2000).

The relative richness and evenness of soil fungal and $\mathrm{N}$-cycling fingerprints were also affected by burning and logging treatments; however, these effects were not as consistent as those found for community structure. In contrast to other studies that have reported declines in (Dahlberg et al., 2001; Twieg et al., 2007), or no effect on (Jones et al. 2003), EcM fungi after clearcut logging, we found a significant increase in the relative richness and evenness of fungal fingerprints in response to clearcut logging, possibly driven by changes in saprotrophic fungi. The removal of trees by logging causes changes in substrate input to the forest floor and, depending on the distribution of woody debris, the diversity of saprotrophic fungi may be affected (Sippola and Renvall, 1999). We found that low-severity burning changed fungal community structure and increased the evenness, but had no effect on the relative richness of fungal fingerprints, a result consistent with findings from other studies (Jonsson et al., 1999). Twieg et al. (2007) found that EcM fungal community composition of a Douglas-fir forest differed with time since burning, while diversity did not change significantly. In contrast, high-severity fire increased both evenness and richness. In general, fire appears to have variable effects on microbial richness, depending on fire severity and site characteristics (Bárcenas-Moreno and Bååth, 2009; Cairney and Bastias, 2007).

The relative richness of denitrifier fingerprints was lowest in the control plots and significantly increased in all disturbance treatments. Our results are consistent with the 
disturbance hypothesis put forward by Walley et al. (1996), who noted changes in Ncycling in forest soils in response to logging and burning, with disturbance encouraging nitrate accumulation. This disturbance effect has also been noted in agricultural soils, where nos $Z$ richness has been found to be higher in cultivated versus native soils (Stres et al., 2004). As burning generally increases soil concentrations of nitrate (Wan et al., 2001), the increase in the relative richness of denitrifier fingerprints in burned sites may be due to an increase in substrate. Although no increases in total $\mathrm{N}$ were seen in our soil analysis, ammonia and nitrate levels usually peak in the first year after fire and then decline (Wan et al., 2001), so the increase in the relative richness of denitrifier fingerprints may reflect a recent, but short-lived, increase in nitrate.

The relative richness of $\mathrm{N}$-fixing bacterial fingerprints decreased in response to fire, but their evenness was not significantly affected. Burning has often been found to negatively impact soil N-fixing bacteria (Shaffer et al., 2000; Yeager et al., 2005). In contrast to fire effects, both clearcut and screefed clearcut soils showed an increase in the relative richness and evenness of $\mathrm{N}$-fixing bacterial fingerprints compared to controls. Clearcutting disrupts the upper soil layers of the forest floor, which can physically disperse N-fixing bacteria into new habitats. In addition, the loss of the tree canopy allows greater light for photosynthetic cyanobacteria, which along with increased soil temperatures (Ballard, 2000), may have provided more niches for $\mathrm{N}$-fixing bacteria to exploit. 
In contrast to the shifts in microbial communities in response to burning and logging treatments, no significant changes in soil chemistry were noted. However, correlations between soil chemical variables and microbial community structure were noted. As the measurements presented in this study were taken over a year after the fire, it is likely that the initial spike in nutrients was missed, as fire-induced increases in $\mathrm{pH}$, ammonia, and soil $\mathrm{N}$ usually persist for only a few months (Hamman et al., 2007; Yeager et al., 2005). In addition, other soil properties such as moisture and temperature, which were not measured, could have influenced soil microbial communities. Both fire and logging treatments produced a decline in tree canopy, which has been associated with large fluctuations in soil temperature and moisture, and higher irradiance (Ballard, 2000; Jones et al., 2003). Finally, although differences were not detected in the mineral soils analysed in this experiment (taken the year before samples for microbial analysis were taken), changes were seen in organic layer in subsequent years (J. Barker, personal communication) and these chemical changes may have leached down into the mineral layer by the time the microbial sampling was carried out.

The greatest differences in fungal, denitrifier and $\mathrm{N}$-fixing community structure, and fingerprint relative richness and evenness, were found in comparisons of burned and logged treatments. Both treatments resulted in loss of the forest floor to varying degrees and by mechanical versus chemical means, but treatments differed with respect to tree survival following the disturbance event. Burned sites were distinguished by the amount of forest floor removed (some remained in the light burn plots, while it was destroyed completely in the severe burn) and the presence of trees (some survived in the light burn). 
Microbial community structure varied between the light and severe burn treatments, which may be partly related to the generally lower relative richness in light burn sites. A more common finding is that higher severity burns cause larger reductions in soil microbial communities (Neary et al., 1999; Yeager et al., 2005). However, there were few differences in microbial communities from clearcut versus screefed clearcut treatments, indicating that the loss of forest floor (at least via mechanical means) did not have a major impact on these communities a year after treatment. When combined, these results suggest that the presence of living trees in the light burn created a unique environment for fungal and N-cycling microbes.

In conclusion, this study demonstrates that burning and logging caused significant shifts in the structure of forest soil fungal, denitrifying, and $\mathrm{N}$-fixing communities in the rhizosphere of 16 month-old Douglas-fir seedlings. In most cases, each disturbance type (light burn, severe burn, and clearcutting) was associated with a distinctive community structure for these microbes. The sharp differences between the light burn and logged sites may indicate that the survival of trees in the former had a stronger impact on soil microbial communities than did removal of the forest floor. It must be noted that this study was based on a single time point, and we do not know what changes may have occurred before and after that time. Changes in microbial community structure are likely to have consequences for nutrient cycling and related processes, and therefore understanding the factors influencing microbial communities in these forests is essential for their proper ecological management. 


\section{Acknowledgements}

This work was supported by a Special Research Opportunity Grant from the Natural

Sciences and Engineering Research Council of Canada (NSERC). We are grateful to

Ashley Gosselin, Jennifer Dupuis, Laura Langille, Rachael Bagnall, Ryan Heinrichs, Ian

Green, Jordan Koopmans, Mark Thompson, and Dana O’Bryan for technical assistance.

We thank Brendan Twieg, Jason Barker and Melanie Jones for statistical help, and Susan

Robertson, Juan Carlos Lopez-Gutierrez, and Jocelyn Campbell for helpful comments on the manuscript.

\section{References}

Ballard, T.M., 2000. Impacts of forest management on northern forest soils. For. Ecol. Manage. 133, 37-42.

Bárcenas-Moreno, G., Bååth, E., 2009. Bacterial and fungal growth in soil heated at different temperatures to simulate a range of fire intensities. Soil Biol. Biochem. 41, 2517-2526.

Blackwood, C.B., Hudleston, D., Zak, D.R., Buyer, J.S., 2007. Interpreting ecological diversity indicies applied to terminal restriction fragment length polymorphism data: Insights from simulated microbial communities. Appl. Environ. Microbiol. 73, 52765283.

Bremner, J.M., 1996. Nitrogen - Total. In: Sparks, D.L., Page, A.L., Helmke, P.A., Loeppert, R.H., Soltanpour, P.N., Tabatabai, M.A., Johnston, C.T., Sumner, M.E. (Eds.), Methods of Soil Analysis. Soil Sci. Soc. Am., Madison, Wisconsin, pp. 1085-1121.

Burke, D.J., Dunham, S.M., Kretzer, A.M., 2008. Molecular analysis of bacterial communities associated with the roots of Douglas fir (Pseudotsuga menziesii) colonized by different ectomycorrhizal fungi. FEMS Microbiol. Ecol. 65, 299-309.

Cairney, J.W.G., Bastias, B.A., 2007. Influences of fire on forest soil fungal communities. Can. J. For. Res. 37, 207-215.

Dahlberg, A., Schimmel, J., Taylor, A.F.S., Johannesson, H., 2001. Post-fire legacy of ectomycorrhizal fungal communities in the Swedish boreal forest in relation to fire severity and logging intensity. Biol. Conserv. 100, 151-161.

Deslippe, J.R., Egger, K.N., Henry, G.H.R., 2005. Impacts of warming and fertilization 
on nitrogen-fixing microbial communities in the Canadian High Arctic. FEMS Microbiol. Ecol. 53, 41-50.

Dighton, J., 2003. Fungi in Ecosystem Processes. Marcel Dekker, New York.

Dong, S., Brooks, D., Jones, M.D., Grayston, S.J., 2007. A method for linking in situ activities of hydrolytic enzymes to associated organisms in forest soils. Soil Biol. Biochem. 39, 2414-2419.

Frey-Klett, P., Garbaye, J., Tarkka, M., 2007. The mycorrhiza helper bacteria revisited. New Phytol. 176, 22-36.

Goodale, C.L., Aber, J.D., 2001. The long-term effects of land-use history on nitrogen cycling in northern hardwood forests. Ecol. Appl. 11, 253-267.

Grogan, P., Bruns, T.D., Chapin, F.S., 2000. Fire effects on ecosystem nitrogen cycling in a Californian bishop pine forest. Oecologia 122, 537-544.

Hamann, A., Wang, T. L., 2006. Potential effects of climate change on ecosystem and tree species distribution in British Columbia. Ecology 87, 2773-2786.

Hamman, S.T., Burke, I.C., Stromberger, M.E., 2007. Relationships between microbial community structure and soil environmental conditions in a recently burned system. Soil Biol. Biochem. 39, 1703-1711.

Izquierdo, J., Nüsslein, K., 2006. Distribution of extensive nifH gene diversity across physical soil microenvironments. Microb. Ecol. 51, 441-452.

Jiménez Esquilin, A.E., Stromberger, M.E., Shepperd, W.D., 2008. Soil scarification and wildfire interactions and effects on microbial communities and carbon. Soil Sci. Soc. Am. J. 72, 111-118.

Jones, M.D., Durall, D.M., Cairney, J.W.G., 2003. Ectomycorrhizal fungal communities in young forest stands regenerating after clearcut logging. New Phytol. 157, 399-422.

Jones, M.D., Twieg, B.D., Ward, V., Barker, J., Durall, D.M., Simard, S.W. Functional complementarity of Douglas-fir ectomycorrhizas for extracellular enzyme activity after wildfire or clearcut logging. Funct. Ecol. In press.

Jonsson, L., Dahlberg, A., Nilsson, M.C., Zackrisson, O., Karen, O., 1999.

Ectomycorrhizal fungal communities in late-successional Swedish boreal forests, and their composition following wildfire. Mol. Ecol. 8, 205-215.

Kalra, Y., Maynard, D., 1991. Methods Manual for Forest Soil and Plant Analysis. Forestry Canada, Edmonton, AB, Canada.

Kandeler, E., Deiglmayr, K., Tscherko, D., Bru, D., Philippot, L., 2006. Abundance of $n a r G, n i r S, n i r K$, and nos $Z$ genes of denitrifying bacteria during primary successions of a 
glacier foreland. Appl. Environ. Microbiol. 72, 5957-5962.

Martin, K.J., Rygiewicz, P.T., 2005. Fungal-specific PCR primers developed for analysis of the ITS region of environmental DNA extracts. BMC Microbiol. 5, 28.

McCune, B. and Grace, J.B., 2002. Analysis of Ecological Communities. MjM Software Design, Gleneden Beach, Oregon, USA.

Neary, D.G., Klopatek, C.C., DeBano, L.F., Ffolliott, P.F., 1999. Fire effects on belowground sustainability: a review and synthesis. For. Ecol. Manage. 122, 51-71.

Osborne, C.A., Rees, G.N., Bernstein, Y., Janssen, P.H., 2006. New threshold and confidence estimates for terminal restriction fragment length polymorphism analysis of complex bacterial communities. Appl. Environ. Microbiol. 72, 1270-1278.

Paul, E.A., Clark, F.E., 1989. Soil Microbiology and Biochemistry. Academic Press, San Diego, CA, USA.

Reich, P.B., Bakken, P., Carlson, D., Frelich, L.E., Friedman, S.K., Grigal, D.F., 2001. Influence of logging, fire, and forest type on biodiversity and productivity in southern boreal forests. Ecology 82, 2731-2748.

Rich, J.J., Heichen, R.S., Bottomley, P.J., Cromack, K., Myrold, D.D., 2003. Community composition and functioning of denitrifying bacteria from adjacent meadow and forest soils. Appl. Environ. Microbiol. 69, 5974-5982.

Scallan, Ú., Liliensiek, K.A., Clipson, N., Connolly, J., 2008. RIBOSORT: a program for automated data preparation and exploratory analysis of microbial community fingerprints. Mol. Ecol. Resour. 8, 95-98.

Schoonmaker, A.L., Teste, F.P., Simard, S.W., Guy, R.D., 2007. Tree proximity, soil pathways and common mycorrhizal networks: their influence on the utilization of redistributed water by understory seedlings. Oecologia 154, 455-466.

Shaffer, B.T., Widmer, F., Porteous, L.A., Seidler, R.J., 2000. Temporal and spatial distribution of the nifH gene of $\mathrm{N}_{2}$ fixing bacteria in forests and clearcuts in western Oregon. Microb. Ecol. 39, 12-21.

Simard, S., 2009. The foundational role of mycorrhizal networks in self-organization of interior Douglas-fir forests. For. Ecol. Manage. 258, S95-107.

Sippola, A.-L., Renvall, P., 1999. Wood-decomposing fungi and seed-tree cutting: a 40year perspective. For. Ecol. Manage. 115, 183-201.

Smith, J.E., Mckay, D., Niwa, C.G., Thies, W.G., Brenner, G., Spatafora, J.W., 2004. Short-term effects of seasonal prescribed burning on the ectomycorrhizal fungal community and fine root biomass in ponderosa pine stands in the Blue Mountains of Oregon. Can. J. For. Res. 34, 2477-2491. 
Stark, K.E., Arsenault, A., Bradfield, G.E., 2006. Soil seed banks and plant community assembly following disturbance by fire and logging in interior Douglas-fir forests of south-central British Columbia. Can. J. Bot. 84, 1548-1560.

Stres, B., Mahne, I., Avguštin, G., Tiedje, J.M., 2004. Nitrous oxide reductase (nosZ) gene fragments differ between native and cultivated Michigan soils. Appl. Environ. Microbiol. 70, 301-309.

Talbot, J.M., Allison, S.D., Treseder, K.K., 2008. Decomposers in disguise: mycorrhizal fungi as regulators of soil $\mathrm{C}$ dynamics in ecosystems under global change. Funct. Ecol. 22, 955-963.

Thies, J.E., 2007. Soil microbial community analysis using terminal restriction fragment length polymorphisms. Soil Sci. Soc. Amer. J. 71, 579-591.

Throbäck, I.N., Enwall, K., Jarvis, A., Hallin, S., 2004. Reassessing PCR primers targeting nirS, nirK and nosZ genes for community surveys of denitrifying bacteria with DGGE. FEMS Microbiol. Ecol. 49, 401-417.

Twieg, B.D., Durall, D.M., Simard, S.W., 2007. Ectomycorrhizal fungal succession in mixed temperate forests. New Phytol. 176, 437-447.

Wallenstein, M.D., Myrold, D.D., Firestone, M., Voytek, M., 2006. Environmental controls on denitrifying communities and denitrification rates: insights from molecular methods. Ecol. Appl. 16, 2143-2152.

Walley, F.L., Van Kessel, C., Pennock, D.J., 1996. Landscape-scale variability of N mineralization in forest soils. Soil Biol. Biochem. 28, 383-391.

Wan, S., Hui, D., Luo, Y., 2001. Fire effects on nitrogen pools and dynamics in terrestrial ecosystems: a meta-analysis. Ecol. Appl. 11, 1349-1365.

White, T.J., Bruns, T., Lee, S., Taylor, J., 1990. Amplification and direct sequencing of fungal ribosomal RNA genes for phylogenetics. In: Innis, M.A., Gelfand, D.H., Sninsky, J.J., White, T.J. (Eds.), PCR Protocols: A Guide to Methods and Applications. Academic Press, New York, pp. 315-322.

Widmer, F., Shaffer, B.T., Porteous, L.A., Seidler, R.J., 1999. Analysis of nifH gene pool complexity in soil and litter at a Douglas fir forest site in the Oregon Cascade mountain range. Appl. Environ. Microbiol. 65, 374-380.

Yeager, C.M., Northup, D.E., Grow, C.C., Barns, S.M., Kuske, C.R., 2005. Changes in nitrogen-fixing and ammonia-oxidizing bacterial communities in soil of a mixed conifer forest after wildfire. Appl. Environ. Microbiol. 71, 2713-2722.

Zehr, J.P., Jenkins, B.D., Short, S.M., Steward, G.F., 2003. Nitrogenase gene diversity and microbial community structure: a cross-system comparison. Environ. Microbiol. 5, 539-554. 


\section{Tables and figures}

Table 1. Chemical characteristics of mineral soils at sites from which soil samples were collected $(n=3)$. Data are presented as means per site \pm 1 SEM.

\begin{tabular}{|c|c|c|c|c|c|}
\hline Treatment & $\begin{array}{l}\mathbf{p H} \\
\left(1: 1 \mathrm{H}_{2} \mathrm{O}\right)\end{array}$ & $\begin{array}{l}\text { Total C } \\
\%\end{array}$ & $\begin{array}{l}\text { Total N } \\
\%\end{array}$ & $\begin{array}{l}\text { Mineral N } \\
\mu g g^{-1}\left(\text { as } N H_{4}-N\right)\end{array}$ & $\begin{array}{l}\text { Available P } \\
\left.\mu g g^{-1} \text { (Bray extractable }\right)\end{array}$ \\
\hline Control & $6.30 \pm 0.1$ & $2.1 \pm 0.3$ & $0.10 \pm 0.01$ & $34.4 \pm 8$ & $191 \pm 73$ \\
\hline Light Burn & $6.13 \pm 0.1$ & $2.0 \pm 0.5$ & $0.10 \pm 0.02$ & $34.4 \pm 9$ & $124 \pm 23$ \\
\hline Severe Burn & $6.17 \pm 0.4$ & $2.4 \pm 0.6$ & $0.10 \pm 0.02$ & $21.3 \pm 3$ & $248 \pm 75$ \\
\hline Clearcut & $5.94 \pm 0.2$ & $2.7 \pm 0.6$ & $0.10 \pm 0.01$ & $26.0 \pm 7$ & $138 \pm 42$ \\
\hline Screefed Clearcut & $5.68 \pm 0.1$ & $2.7 \pm 0.1$ & $0.11 \pm 0.01$ & $21.1 \pm 4$ & $142 \pm 31$ \\
\hline $\begin{array}{l}P \text { from oneway } \\
\text { ANOVA }\end{array}$ & 0.23 & 0.73 & 0.99 & 0.45 & 0.49 \\
\hline
\end{tabular}

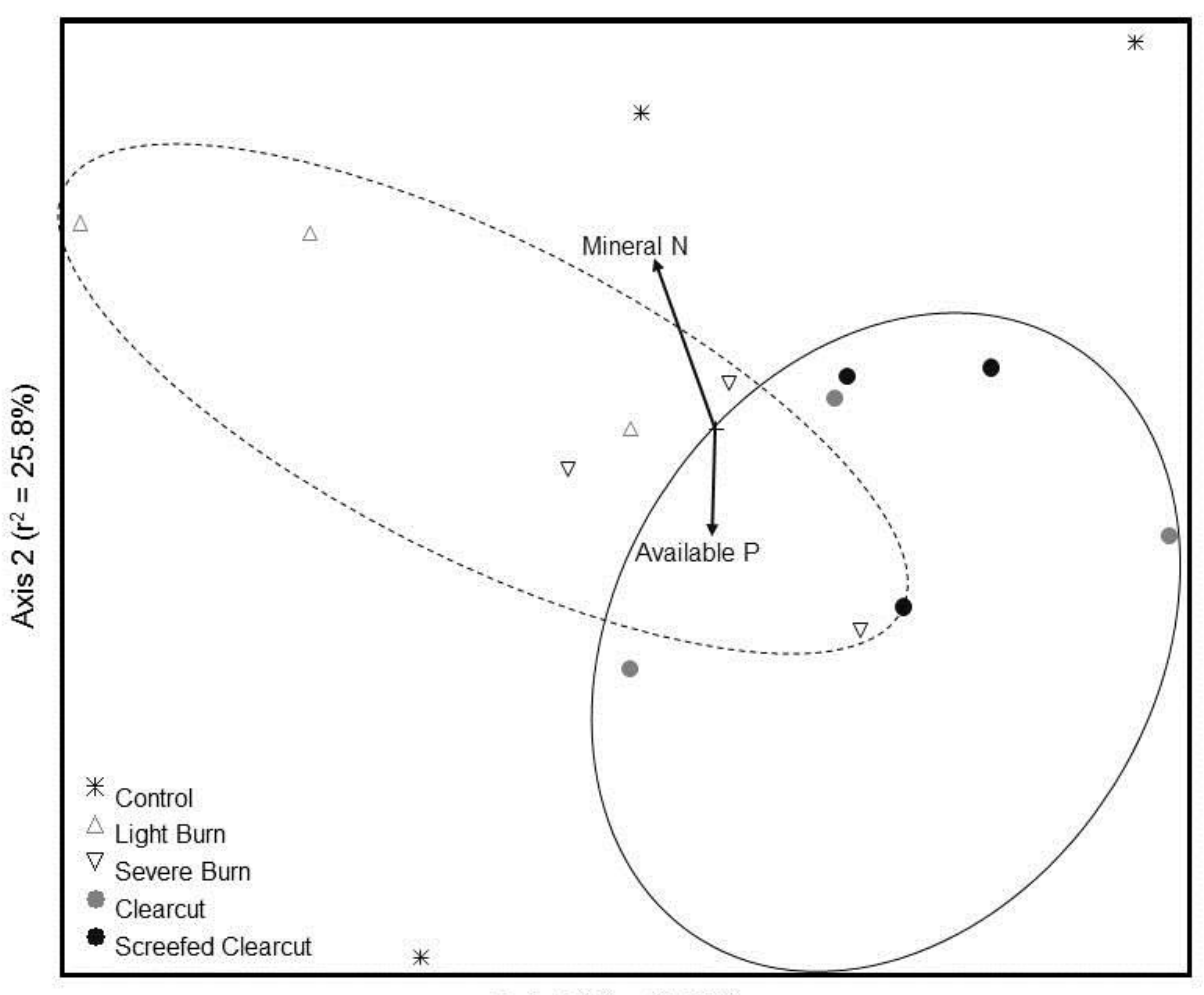

Axis $1\left(r^{2}=45.2 \%\right)$ 
Figure 1. NMS plot of fungal community structure, as assessed by LH-PCR profiles. $\mathrm{r}^{2}$ values represent the variance explained by each axis. Unbroken circle indicates clustering of clearcut and clearcut screefed sites, while the dashed oval indicates clustering of the light burn and severe burn sites. Each site point represents the mean of 24 sub-samples. Soil chemical variables exhibiting significant correlations with fungal community structure are shown as vectors pointing in the direction of the strongest correlations, while the length of the vector indicates the magnitude of the relationship. Stress=14.9, instability $=0.00001$, Monte Carlo test, $P<0.05$ for both axes. 
Table 2. Results of Multi-Response Permutation Procedures (MRPP) performed on fungal, denitrifier, and N-fixing bacteria community profiles from different treatments. $P$ values have not been corrected for multiple comparisons.

\begin{tabular}{|c|c|c|c|c|c|c|}
\hline & \multicolumn{2}{|c|}{ Fungi } & \multicolumn{2}{|c|}{ Nitrifiers } & \multicolumn{2}{|c|}{$\mathrm{N}$-fixing bacteria } \\
\hline & $A$ & $P$ & $A$ & $P$ & $A$ & $P$ \\
\hline \multicolumn{7}{|l|}{ Overall } \\
\hline Treatment & 0.03578619 & 0.00000000 & 0.06358676 & 0.00000000 & 0.06914263 & 0.00000000 \\
\hline \multicolumn{7}{|l|}{ Individual Comparisons } \\
\hline Control v Light Burn & 0.01817827 & 0.00082954 & 0.05953355 & 0.00000099 & 0.04097917 & 0.00006982 \\
\hline Control v Severe Burn & 0.01922923 & 0.00029456 & 0.01618045 & 0.04249394 & 0.01803734 & 0.01600365 \\
\hline Control v Clearcut & 0.01427931 & 0.00994309 & 0.01504940 & 0.04304260 & 0.02924892 & 0.00229142 \\
\hline Control v Screefed Clearcut & 0.02778628 & 0.00007979 & 0.04976024 & 0.00009470 & 0.04050792 & 0.00027757 \\
\hline Light Burn v Severe Burn & 0.01978912 & 0.00016397 & 0.05251918 & 0.00011396 & 0.04415094 & 0.00095296 \\
\hline Light Burn v Clearcut & 0.03465740 & 0.00003450 & 0.05849611 & 0.00003572 & 0.10194790 & 0.00000001 \\
\hline Light Burn v Screefed Cl & 0.03952842 & 0.00000103 & 0.06834142 & 0.00000296 & 0.11852929 & 0.00000001 \\
\hline Severe Burn v Clearcut & 0.01958569 & 0.00524209 & 0.01841375 & 0.04416325 & 0.02804228 & 0.00433724 \\
\hline Severe Burn v Screefed Clearcut & 0.02954002 & 0.00009033 & 0.05403423 & 0.00060599 & 0.03073086 & 0.00329105 \\
\hline${ }^{\mathrm{a}}$ Clearcut v Screefed Clearcut & $0.44856(\mathrm{~F})$ & 0.805800 & $3.8469(\mathrm{~F})$ & 0.000400 & $2.3050(\mathrm{~F})$ & 0.067600 \\
\hline
\end{tabular}

${ }^{a}$ A separate, nested analysis (perMANOVA) was performed on clearcut and screefed clearcut treatments to confirm results, as these treatments were not independent. 

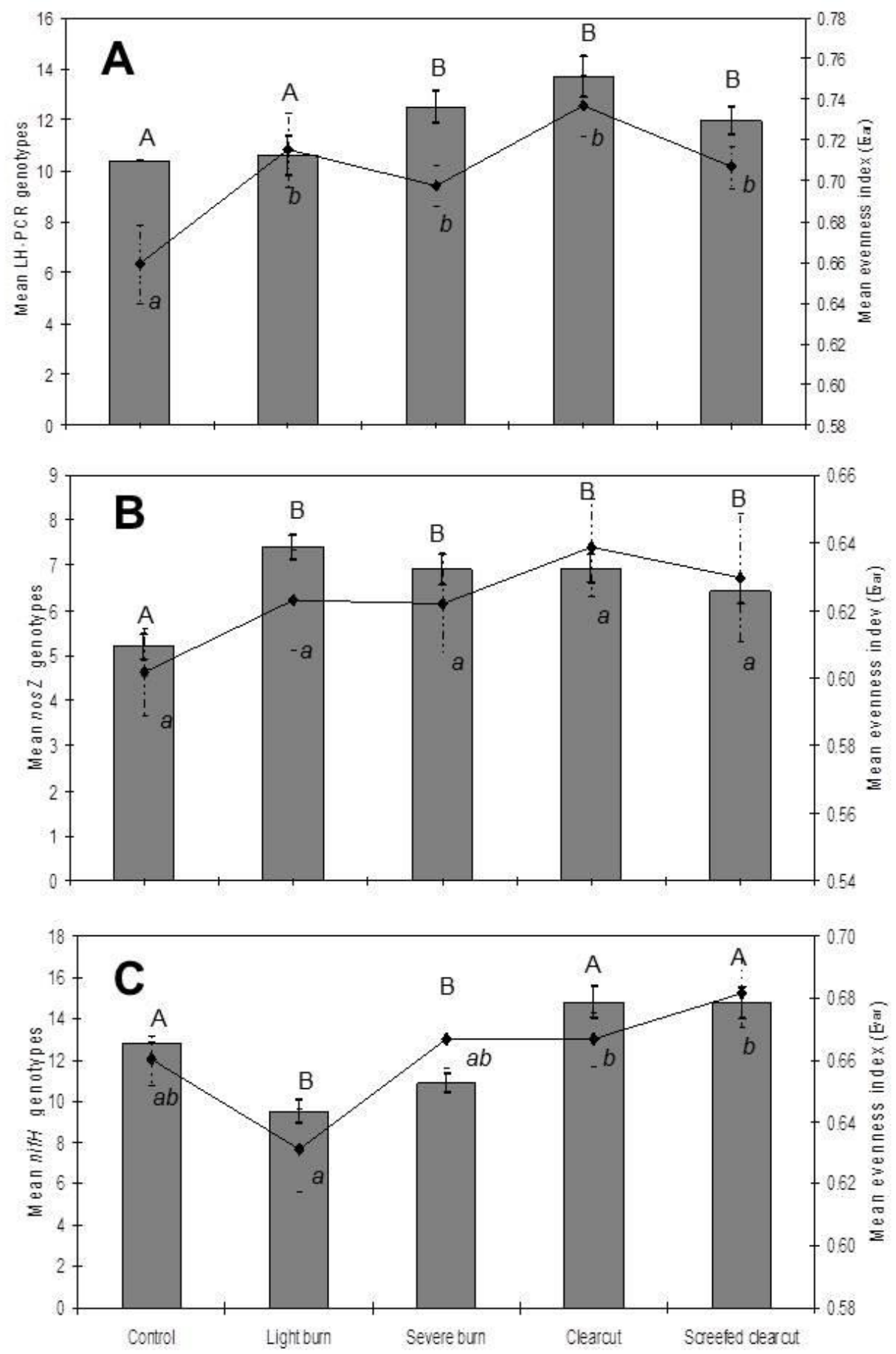

Figure 2. Plots of the relative richness (bars) and evenness (lines) of fingerprints for A) fungi, B) denitrifiers, and C) N-fixing bacteria, as measured by LH-PCR or T-RFLP 
genotype profiles. Same letter (uppercase, relative richness; lowercase, evenness) denotes no significant difference between treatments in a gene $(P<0.05)$. The total number of genotypes included in analysis was 111 for fungi (LH-PCR), 43 for denitrifiers (nosZ TRFLP), and 62 for N-fixing bacteria (nifH T-RFLP).

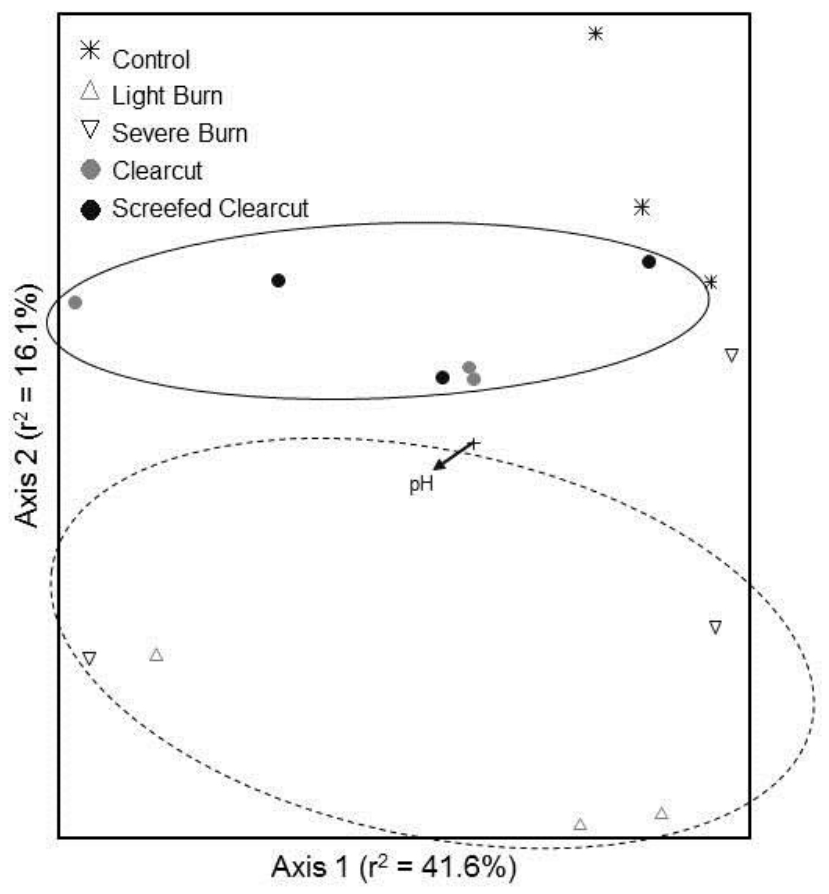

Figure 3. NMS plot of denitrifier community structure, as assessed by nosZ T-RFLP profiles. $\mathrm{r}^{2}$ values represent the variance explained by each axis. Unbroken oval indicates clustering of clearcut and clearcut screefed sites, while the dashed oval indicates clustering of most of the burned sites. Each site point represents the mean of 24 subsamples. Soil chemical variables exhibiting significant correlations with denitrifier community structure are shown as vectors pointing in the direction of the strongest 
correlations, while the length of the vector indicates the magnitude of the relationship.

Stress $=13.1$, instability $=0.00136$, Monte Carlo test, $P<0.05$ for both axes.

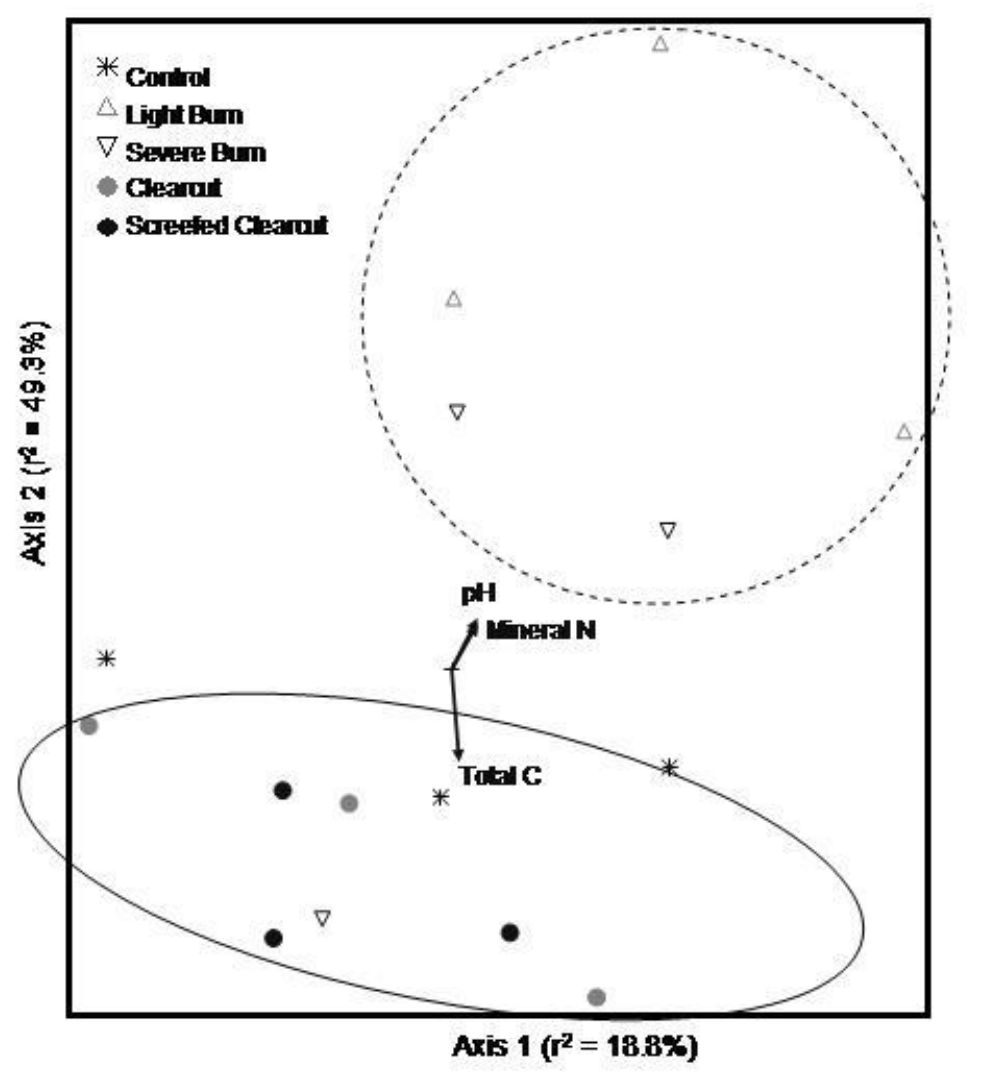

Figure 4. NMS plot of N-fixing community structure, as assessed by nifH T-RFLP

profiles. $\mathrm{r}^{2}$ values represent the variance explained by each axis. Unbroken oval indicates clustering of clearcut and clearcut screefed sites, while the dashed oval indicates clustering of the burned sites. Each site point represents the mean of 24 sub-samples. Soil chemical variables exhibiting significant correlations with $\mathrm{N}$-fixing bacterial community structure are shown as vectors pointing in the direction of the strongest correlations, while the length of the vector indicates the magnitude of the relationship. Stress $=10.2$, instability $=0.00001$, Monte Carlo test, $P<0.05$ for both axes. 
Supplementary Information

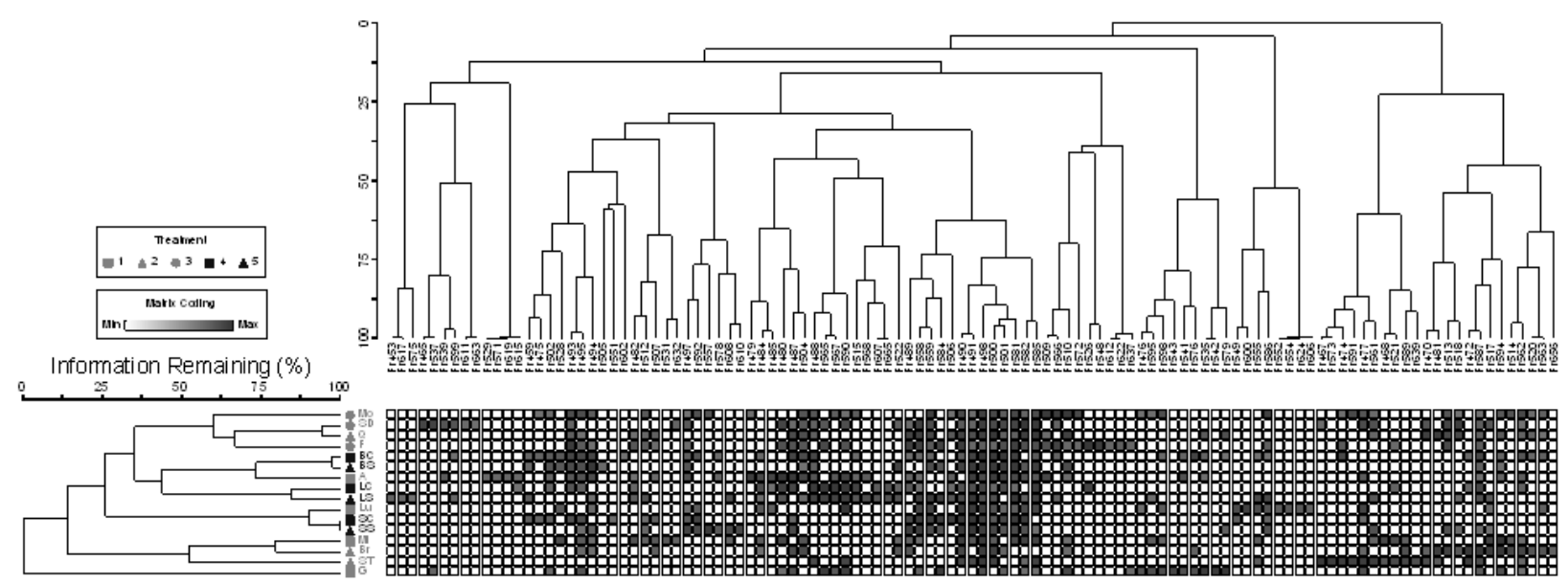

Figure S1. Two-way cluster analysis of fungal genotypes, as assessed by LH-PCR

profiles. Dendrogram generated using the Sorensen index and the flexible beta $(\beta=-0.25)$ method for linking groups. Labels in the horizontal dendrogram are coded according to treatment. Labels in the vertical dendrogram indicate genotype fragment size. 


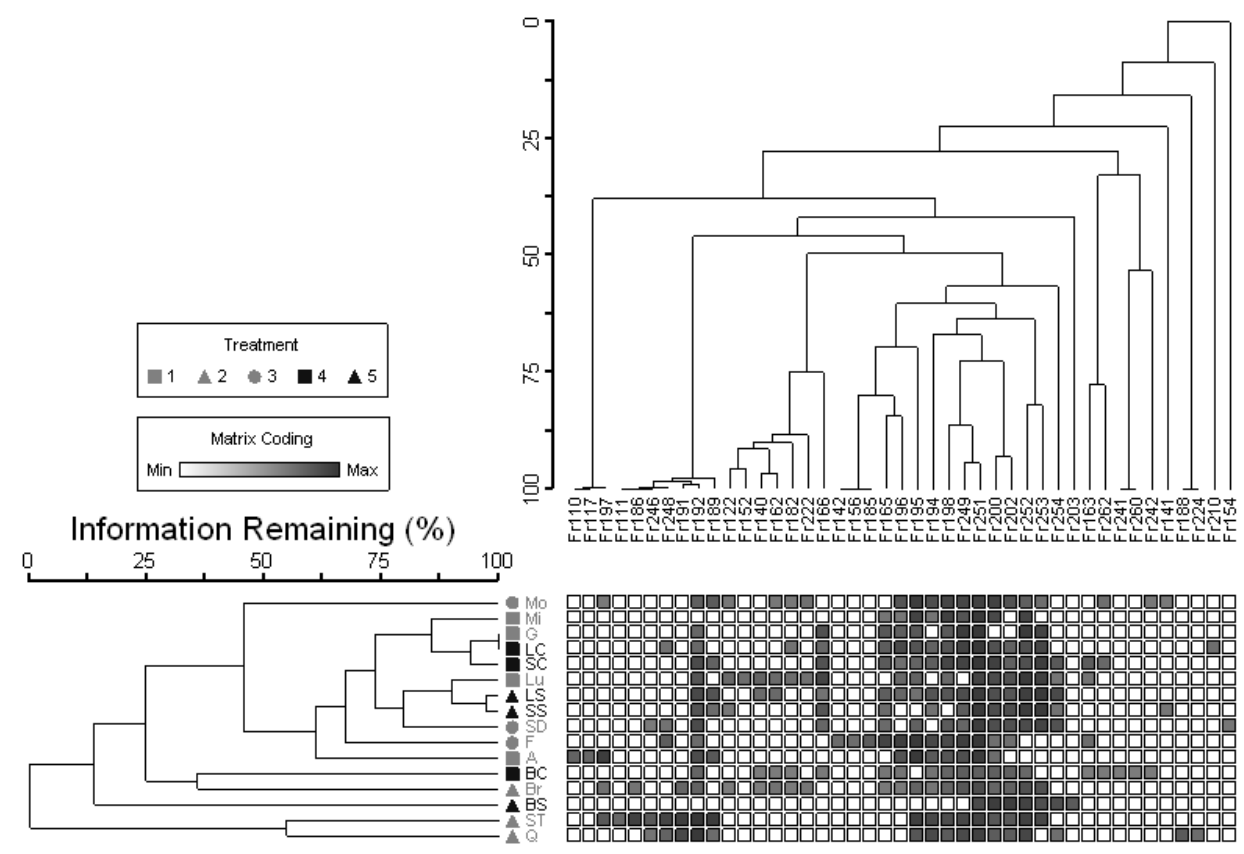

Figure S2. Two-way cluster analysis of denitrifier genotypes, as assessed by nosZ T-

RFLP profiles. Dendrogram generated using the Sorensen index and the flexible beta $(B=$ -0.25) method for linking groups. Labels in the horizontal dendrogram are coded according to treatment. Labels in the vertical dendrogram indicate genotype fragment size. 


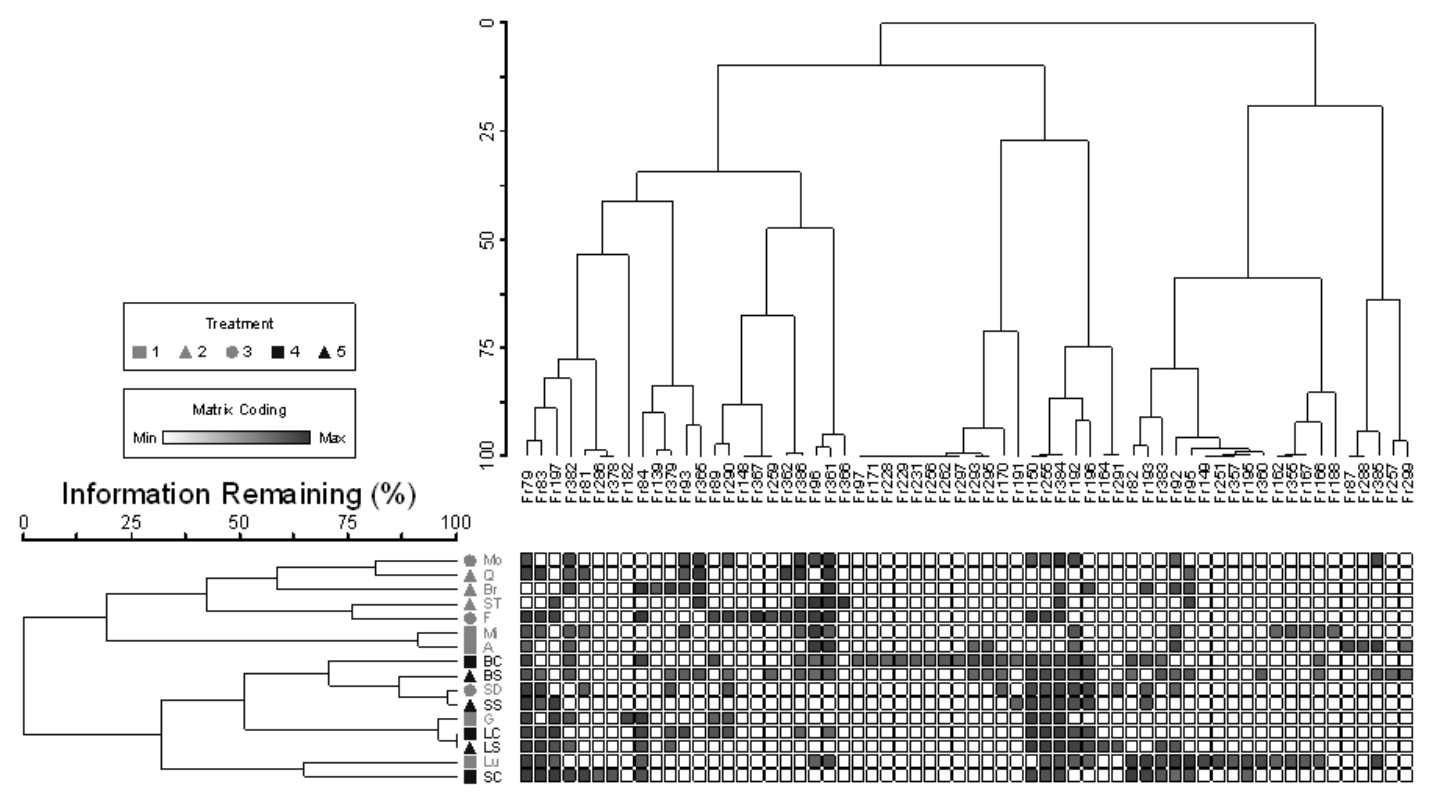

Figure S3. Two-way cluster analysis of N-fixing bacterial genotypes, as assessed by nifH T-RFLP profiles. Dendrogram generated using the Sorensen index and the flexible beta $(ß=-0.25)$ method for linking groups. Labels in the horizontal dendrogram are coded according to treatment. Labels in the vertical dendrogram indicate genotype fragment size. 